\title{
Modulation of airway epithelial cell functions by Pidotimod: NF-kB cytoplasmatic expression and its nuclear translocation are associated with an increased TLR-2 expression
}

Sonia Carta, Michela Silvestri and Giovanni A Rossi

\begin{abstract}
Background: Recurrent respiratory infections are one of the most important causes of morbidity in childhood. When immune functions are still largely immature, the airway epithelium plays a primary defensive role since, besides providing a physical barrier, it is also involved in the innate and the adaptive immune responses. A study was therefore designed to evaluate in vitro whether pidotimod, a synthetic dipeptide able to stimulate the inflammatory and immune effector cells, could activate bronchial epithelial cell functions involved in response to infections.
\end{abstract}

Methods: BEAS-2B cell line (human bronchial epithelial cells infected with a replication-defective Adenovirus $12-S V 40$ virus hybrid) were cultured in the presence of pidotimod, with or without tumor necrosis factor (TNF)-a or zymosan to assess: a) intercellular adhesion molecule (ICAM)-1 expression, by flow cytometry; b) toll-like receptor (TLR)-2 expression and production, by immunofluorescence flow cytometry and western blotting; d) interleukin (IL)-8 release, by enzyme-linked immunosorbent assay (ELISA); e) activated extracellular-signal-regulated kinase (ERK1/2) phosphorylation and nuclear factor-kappa B (NF-kB) activation, by western blotting.

Results: The constitutive expression of ICAM-1 and IL-8 release were significant up-regulated by TNF-a (ICAM-1) and by TNF-a and zymosan (IL-8), but not by pidotimod. In contrast, an increased TLR-2 expression was found after exposure to pidotimod 10 and $100 \mu \mathrm{g} / \mathrm{ml}(\mathrm{p}<0.05)$ and to the association pidotimod $100 \mu \mathrm{g} / \mathrm{ml}+$ TNF- $a(p<0.05)$. Western blot analysis substantiated that the constitutive TLR-2 expression was significantly increased after exposure to all the stimuli. Finally, while a remarkable inhibition of TNF-a -induced ERK1/2 phosphorylation was observed in the presence of pidotimod, both TNF- $a$ and pidotimod were effective in inducing NF-kB protein expression in the cytoplasm and its nuclear translocation.

Conclusion: Through different effects on ERK1/2 and NF-kB, pidotimod was able to increase the expression of TLR-2 proteins, surface molecules involved in the initiation of the innate response to infectious stimuli. The lack of effect on ICAM-1 expression, the receptor for rhinovirus, and on IL-8 release, the potent chemotactic factor for neutrophils (that are already present in sites of infection), may represent protective functions. If confirmed in vivo, these activities may, at least in part, clarify the mechanism of action of this molecule at airway level.

Keywords: Recurrent respiratory infections, Immunostimulants, Toll like receptor-2, ICAM-1

\footnotetext{
* Correspondence: giovannirossi@ospedale-gaslini.ge.it

Pediatric Allergy and Pulmonary Disease Unit, Istituto Giannina Gaslini, Via G Gaslini 5, 16147, Genoa, Italy
} 


\section{Background}

Respiratory tract infections, presenting as common cold, rhinosinusitis, tonsillopharyngitis, otitis media and tracheobronchitis, with or without airway obstruction, are highly prevalent among young children [1-3]. These infections have not only an impact on children's health and well-being, but also generate high medical costs and indirect costs for the family and the society [4,5]. Indeed, on average, young children experience 4-6 upper respiratory tract infections per year [6], but when they grow older, the incidence of these infections decreases, probably as a result of a more mature immune defenses and improved anatomical conditions. The most common pathogens involved in the etiology of recurrent respiratory infections are human rhinoviruses (HRV), adenovirus, parainfluenza virus, respiratory syncytial virus, enterovirus, human metapneumovirus and coronavirus, in addition to influenza viruses and rhinovirus [6,7]. A major pathogenetic role is played by rhinoviruses, the most frequent causative agents of both upper and lower respiratory tract infections in infants and young children that are able to induce a broad variety of clinical outcomes, ranging from asymptomatic infections to severe respiratory diseases requiring hospitalization $[6,8]$.

Being protected by a highly specialized innate and adaptative immune system, the surface of the respiratory tract acts as a selective barrier, maintaining the integrity of tissue compartments and impeding entry of inhaled majority microbial pathogens, irritants and allergens [9]. Besides providing a physical and functional barrier to external agents, airway epithelial cells are also actively involved in initiation of the host inflammatory and immune responses through the release of early inflammatory mediators $[9,10]$. Through the activation of their surface pattern recognition receptors, that detect environmental stimuli, airway epithelial cells secrete endogenous danger signals, thereby activating dendritic cells and bridging innate and adaptive immunity [9-11].

Extensive research into the role of inflammatory mediators in the pathogenesis of respiratory insufficiency syndrome (RIS), has produced evidence for increased concentrations of several mediators, such as kinins, leukotrienes, histamine, interleukins 1,6 , and 8 , tumor necrosis factor (TNF)- $\alpha$, and regulated by activation normal T cell expressed and secreted (RANTES) in the nasal secretions of patients with colds [12-14]. The host response mechanisms triggered by viral infection and their efficacy in protecting the host are, however, extremely complex and far from being resolved. Furthermore an exaggerated inflammatory reaction, may increase the damage at airway levels, rather than protect from infection [12-15].

Several studies have shown that atopy and attendance at large daycare are associated with more common respiratory infections during the preschool years $[16,17]$, while only in a minority of patients partial IgA and/or IgG subclass deficiency can be demonstrated [18]. However, a defective (immature) inflammatory and/or immune response at airway epithelial level may also be involved [19].

With this background a study was designed to evaluate in vitro whether pidotimod, a synthetic dipeptide active on both innate and adaptive immunity [20], could modulate airway epithelial cells functions involved in the response to respiratory infections. We evaluate intercellular adhesion molecule (ICAM)-1 and toll like receptor (TLR)-2 expression, interleukin (IL)-8 release and investigate the possible involvement of the protein complex nuclear factor kappalight-chain-enhancer of activated B cells (NF-kB) and the activated extracellular-signal-regulated kinase (ERK)1/2 phosphorylation.

\section{Materials and methods}

\section{Cell culture}

A human bronchial epithelial cells line (BEAS-2B) (ATCC, Manassas, VA, USA), derived from human bronchial epithelium transformed by an adenovirus (12-SV40 hybrid virus) was used in all the experiments [21]. These cells, that retain electron microscopic features of epithelial cells and show positive staining with antibodies to cytokeratin, were grown as monolayer in a 1:1 mixture of Laboratory of Human Carcinogenesis (or LHC)-9 medium (Invitrogen SRL; Milan, Italy) and RPMI 1640 medium (EuroClone; Milan, Italy).

\section{Pidotimod preparation}

Pidotimod (99.6\% purity) was gently provided by Valeas S.p.A. (Milan, Italy). Stock standard solution was prepared in PBS at the concentration of $35 \mathrm{mg} / \mathrm{ml}$ [20].

\section{Assessment of cell viability}

BEAS-2B were treated with pidotimod $(10,100 \mu \mathrm{g} / \mathrm{ml})$, $10 \mathrm{ng} / \mathrm{ml} \mathrm{TNF}-\alpha$ or $50 \mu \mathrm{g} / \mathrm{ml}$ zymosan used alone or in association, at different time ( 24 and $48 \mathrm{~h}$ ), the percent viability was measured by trypan blue dye exclusion test (EuroClone S.p.A., Mi, Italy) [22]. Cells were counted in a Neubauer chamber and viable cells were detected based on the ability to exclude the dye. Non-viable cells were blue due to defects in the cell membrane.

\section{Flow cytometry}

BEAS-2B cells were grown to $90 \%$ confluence in 12 well culture plate in the presence of pidotimod (10 and 100 $\mu \mathrm{g} / \mathrm{ml}), 10 \mathrm{ng} / \mathrm{ml}$ TNF- $\alpha, 50 \mu \mathrm{g} / \mathrm{ml}$ zymosan used alone or in association, or pre-treated with pidotimod for different time and then stimulated with TNF- $\alpha$ or zymosan for another $24 \mathrm{~h}$. For each analysis $2 \times 10^{6}$ cells were incubated with FITC-Conjugated mouse anti ICAM-1 (Invitrogen S.r.l., San Giuliano Milanese, Italy) and with an anti-mouse TLR-2 (Santa Cruz Biotechnology Inc, 
Segrate, Milan, Italy) antibody for $1 \mathrm{~h}$ [22]. TLR-2 expression was detected using a goat anti-mouse antibody (Alexa Fluor488; Invitrogen). The cells were washed, resuspended in PBS and immediately analyzed with FACS Calibur flow cytometer (Becton Dickson, Milan, Italy) using Cell Quest software [22]. Mean fluorescent intensity was compared with control staining using an irrelevant isotype-matched mouse monoclonal antibody.

\section{Immunofluorescence microscopy}

BEAS-2B cells were cultured on 8-well glass Labtek slides (Nalge Nunc International) under different experimental conditions. The cells were treated with $100 \mu \mathrm{g} / \mathrm{ml}$ pidotimod or $10 \mathrm{ng} / \mathrm{ml}$ TNF- $\alpha$ used alone or in association, for $24 \mathrm{~h}$. BEAS-2B cells were fixed in ice-cold methanol for $5 \mathrm{~min}$. After blocking BEAS-2B were labelled with mouse anti TLR-2 Abs (TL2.1; Santa Cruz Biotechnology), then with a goat anti-mouse antibody (Alexa Fluor488; Invitrogen).

\section{IL-8 assay}

BEAS-2B cells were incubated for $24 \mathrm{~h}$ with $10 \mathrm{ng} / \mathrm{ml}$ TNF- $\alpha, 50 \mu \mathrm{g} / \mathrm{ml}$ zymosan or pidotimod $(10,100 \mu \mathrm{g} / \mathrm{ml})$, in the absence or presence of TNF- $\alpha$ and zymosan. After the treatments the supernatant were collected and IL-8 levels were quantified by enzyme-linked immunosorbent assay (ELISA) kits (R\&D Systems, Minneapolis, USA), according to the manufacturer's instructions.

Preparation of cytoplasmic extracts for TLR-2 analysis and activated extracellular-signal-regulated kinase (ERK) 1/2 analysis

For TLR-2 analysis, BEAS-2B cells were grown to $90 \%$ confluence in 24 well plates and treated with pidotimod (10, $100 \mu \mathrm{g} / \mathrm{ml}), 10 \mathrm{ng} / \mathrm{ml}$ TNF- $\alpha, 50 \mu \mathrm{g} / \mathrm{ml}$ zymosan, used alone or in association, for $24 \mathrm{~h}$. For ERK1/2 analysis, cells were equally plated and cultured until $90 \%$ confluence and then exposed to pidotimod, TNF- $\alpha$ or TNF- $\alpha$ with pidotimod, for 5 to $60 \mathrm{~min}$ [23]. After the treatments the cells were scraped and lysed with lysis buffer $[20 \mathrm{mM}$ Tris- $\mathrm{HCl}$ buffer ( $\mathrm{pH} 7.4$ )], containing $150 \mathrm{mM} \mathrm{NaCl}, 1$ mM EDTA, 1nM EGTA, $1 \mathrm{mM}$ sodium orthovanadate, $1 \%(\mathrm{v} / \mathrm{v})$ Triton X-100, $1 \mathrm{mM}$ PMSF, $10 \mu \mathrm{g} / \mathrm{ml}$ leupeptin, and $10 \mu \mathrm{g} / \mathrm{ml}$ aprotinin) for $5 \mathrm{~min}$ on ice. The lysates were then centrifuged at $12,000 \mathrm{~g}$ for $5 \mathrm{~min}$ [23].

\section{Preparation of cytoplasmic and nuclear extracts for NF-kB analysis}

BEAS-2B cells were grow to $90 \%$ confluence in 6 well plates and treated with $100 \mu \mathrm{g} / \mathrm{ml}$ pidotimod, TNF- $\alpha$ or TNF- $\alpha$ with pidotimod for $1 \mathrm{~h}$. Extracts were prepared using a method described by Leslie J. Crofford [24]. Briefly, cells resuspended in cytoplasmic buffer $(10 \mathrm{mM}$ HEPES, pH 7.9, 10 mM KC1, 0.1 mM EDTA, $0.1 \mathrm{mM}$
EGTA, $1 \mathrm{mM}$ dithiothreitol [DTT], and protease inhibitors) on ice for 15 minutes, after which Triton X-100 was added to a final concentration of $0.25 \%$. Intact nuclei were pelleted by centrifugation, and the cytoplasmic extract was immediately frozen. Nuclei were resuspended in highsalt buffer (20 mM HEPES, pH 7.9, 400 mM NaCI, 1 mM EDTA, $1 \mathrm{mM}$ EGTA, $1 \mathrm{mM}$ DTT, and protease inhibitors) for $15 \mathrm{~min}$ at $4^{\circ} \mathrm{C}$. The nuclear extract was collected after centrifugation at $13,500 \mathrm{~g}$ for $5 \mathrm{~min}$ at $4^{\circ} \mathrm{C}$.

\section{Western blot analysis}

The protein concentration of the lysates was measured using the Bio-Rad protein assay. Equal amounts of protein were resolved with $10 \%$ or $12 \%$ SDS-PAGE and transferred to PVDF membranes. Membranes were blotted for TLR-2 and p65 NF-kB (Santa Cruz Biotechnology), total ERK1/2 and phosphorylated ERK1/2 (Cell Signaling, Technology, Beverly, MA, USA), GAPDH (Novus Biological, Inc, Segrate, Milan, Italy), Lamin A/C (Santa Cruz Biotechnology Inc, Segrate, Milan, Italy) [23]. After incubation with HPR-conjugated anti-rabbit o anti-mouse antibody (Cell Signaling Technology), the bands were detected using enhanced chemoluminescence (ECL, Pierce, Celbio, Italy) and relevant band intensities were quantified using a Versadoc Imaging System model 3000 (Biorad Laboratories, Hercules, CA, USA).

\section{Statistical analysis}

Statistical evaluation was performed using the statistical software package GraphPad Prism 3.02 (GraphPad Software, San Diego, CA, USA). The results were expressed as mean \pm standard error of the mean (SEM) and $t$ test or the Mann-Whitney test were used. Probability values $(\mathrm{P}<0.05)$ were considered as statistically significant.

\section{Results}

Airway epithelial cell viability

Assessment of BEAS-2B cells by trypan blue dye exclusion test showed that after $24 \mathrm{~h}$ incubation, cell viability $>90 \%$ and was similar in cultures containing pidotimod (10 e $100 \mu \mathrm{g} / \mathrm{ml}$ ), zymosan, TNF- $\alpha$ or pidotimod plus zymosan or TNF- $\alpha$ (not shown). Similar results were obtained exposing BEAS-2B cells for $48 \mathrm{~h}$ (not shown).

\section{ICAM-1 expression by airway epithelial cells}

To investigate the effect of pidotimod on ICAM-1 expression, BEAS-2B cells were exposed to pidotimod (10, $100 \mu \mathrm{g} / \mathrm{ml})$, TNF- $\alpha(10 \mathrm{ng} / \mathrm{ml})$ or pre-treated with pidotimod for different time $(4,12$ or $24 \mathrm{~h}$ ) and then stimulated with TNF- $\alpha$ for additional $24 \mathrm{~h}$. The cells were stained with antibody anti-human ICAM-1. Result obtained by flow cytometric analysis showed that the constitutive expression of ICAM-1 by BEAS-2B cells was significant up-regulated by $24 \mathrm{~h}$ exposure of the 
cells to TNF- $\alpha(\mathrm{p}<0.05)$, but not to pidotimod (Figure 1A). No changes in ICAM-1 expression were obtained exposing the cells to pidotimod for $36 \mathrm{~h}$ or $48 \mathrm{~h}$ (Figure 1B) and no modifications in the TNF- $\alpha$-induced increase in ICAM-1 expression was observed pre-treating the cells with pidotimod for 4, 12 or 24 h (Figure 1C).

\section{TLR-2 expression by airway epithelial cells}

To analyze the expression of TLR-2, BEAS-2B cells were exposed for $24 \mathrm{~h}$ to pidotimod (10 and $100 \mu \mathrm{g} / \mathrm{ml}$ ), TNF- $\alpha$, zymosan or pidotimod with TNF- $\alpha$ or zymosan. The enhanced TLR-2 expression induced by exposure to the stimuli detected by immunofluorescence microscopy (Figure 2A) was then quantified by flow cytometric analysis and found to be significant only after exposed to pidotimod 10 or $100 \mu \mathrm{g} / \mathrm{ml}(\mathrm{p}<0.05)$ and the association pidotimod $100+$ TNF- $\alpha(\mathrm{p}<0.05)$ (Figure $2 \mathrm{~B})$. Western blot (Figure 3A) and densitometric analysis demonstrated that, at protein level, the effect was statistically significant also for TNF- $\alpha(\mathrm{p}<0.05)$, zymosan $(\mathrm{p}<0.01)$ and for the combinations zymosan with pidotimod $(\mathrm{p}<$ 0.01) (Figure 3B). Pre-incubation of the cells with pidotimod for 4,12 or $24 \mathrm{~h}$ did not modify the results (not shown).

\section{IL-8 release}

BEAS-2B cells were exposed for $24 \mathrm{~h}$ to pidotimod (100 $\mu \mathrm{g} / \mathrm{ml})$, TNF- $\alpha$, zymosan or TNF- $\alpha$ and zymosan with pidotimod. The detectable IL-8 concentrations found in the supernatants of cell cultured in medium alone, were significantly increased in cell culture exposed for $24 \mathrm{~h}$ to TNF- $\alpha$ or zymosan $(\mathrm{p}<0.01$, each comparison), but not to pidotimod (Figure 4). No further modifications in the TNF- $\alpha$ - or zymosan-induced increase in IL- 8 release was observed with the addition of pidotimod to the cell cultures. Finally, preincubation of the cells with pidotimod did not modify the results (not shown).

\section{ERK1/2 pathway activation}

For ERK1/2 analysis, confluent BEAS-2B cells were exposed to pidotimod, TNF- $\alpha$ or TNF- $\alpha$ with pidotimod for 5 to $60 \mathrm{~min}$. An increase threonine/tyrosine phosphorylation of ERK1/2 was already detectable by Western blotting at $5 \mathrm{~min}$ in cell exposed to TNF- $\alpha$, but not to pidotimod $(100 \mu \mathrm{g} / \mathrm{ml})$ (Figure $5 \mathrm{~A})$. In contrast, the addition of pidotimod $(100 \mu \mathrm{g} / \mathrm{ml})$ to the cells exposed to TNF- $\alpha$ induced a detectable decrease in ERK $1 / 2$ phosphorylation (Figure 5A). Densitometric analysis demonstrated that the inhibitory effect was complete at 5, 30 and $60 \mathrm{~min}$ (Figure 5B).

\section{NF-kB expression and translocation}

BEAS-2B cells were treated with TNF- $\alpha, 100 \mu \mathrm{g} / \mathrm{ml}$ pidotimod or TNF- $\alpha$ with pidotimod for $1 \mathrm{~h}$. NF-kB was

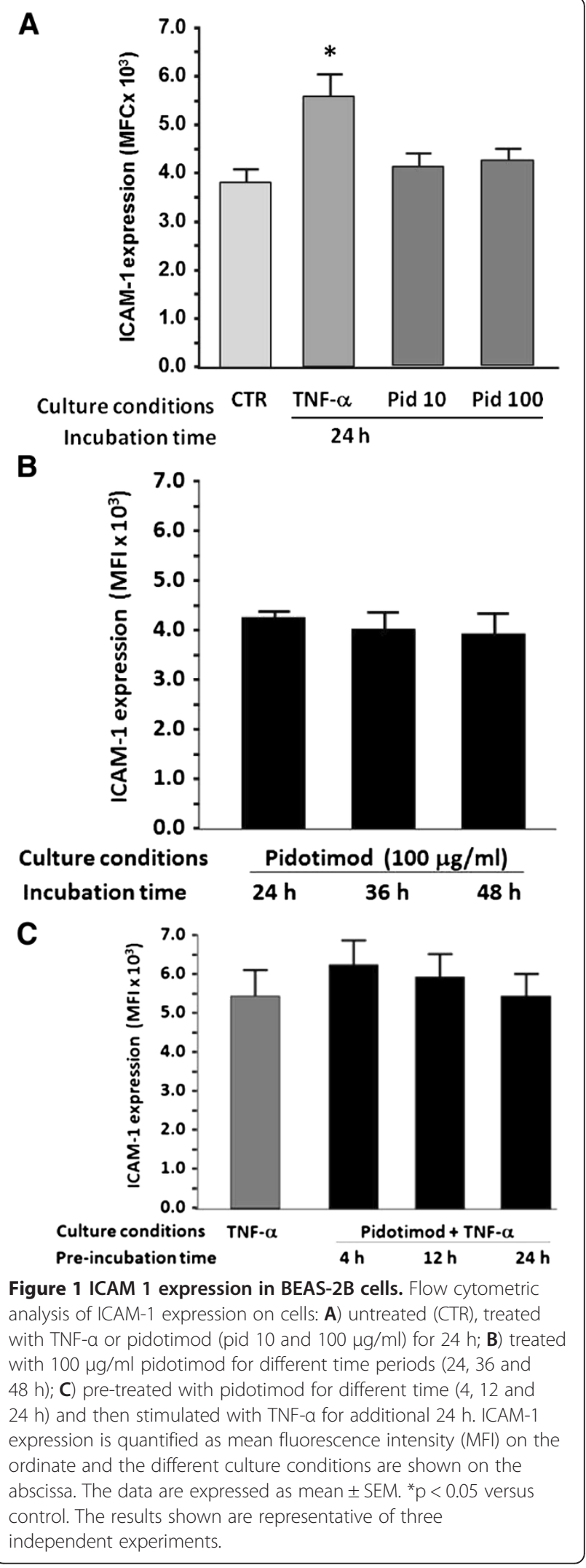




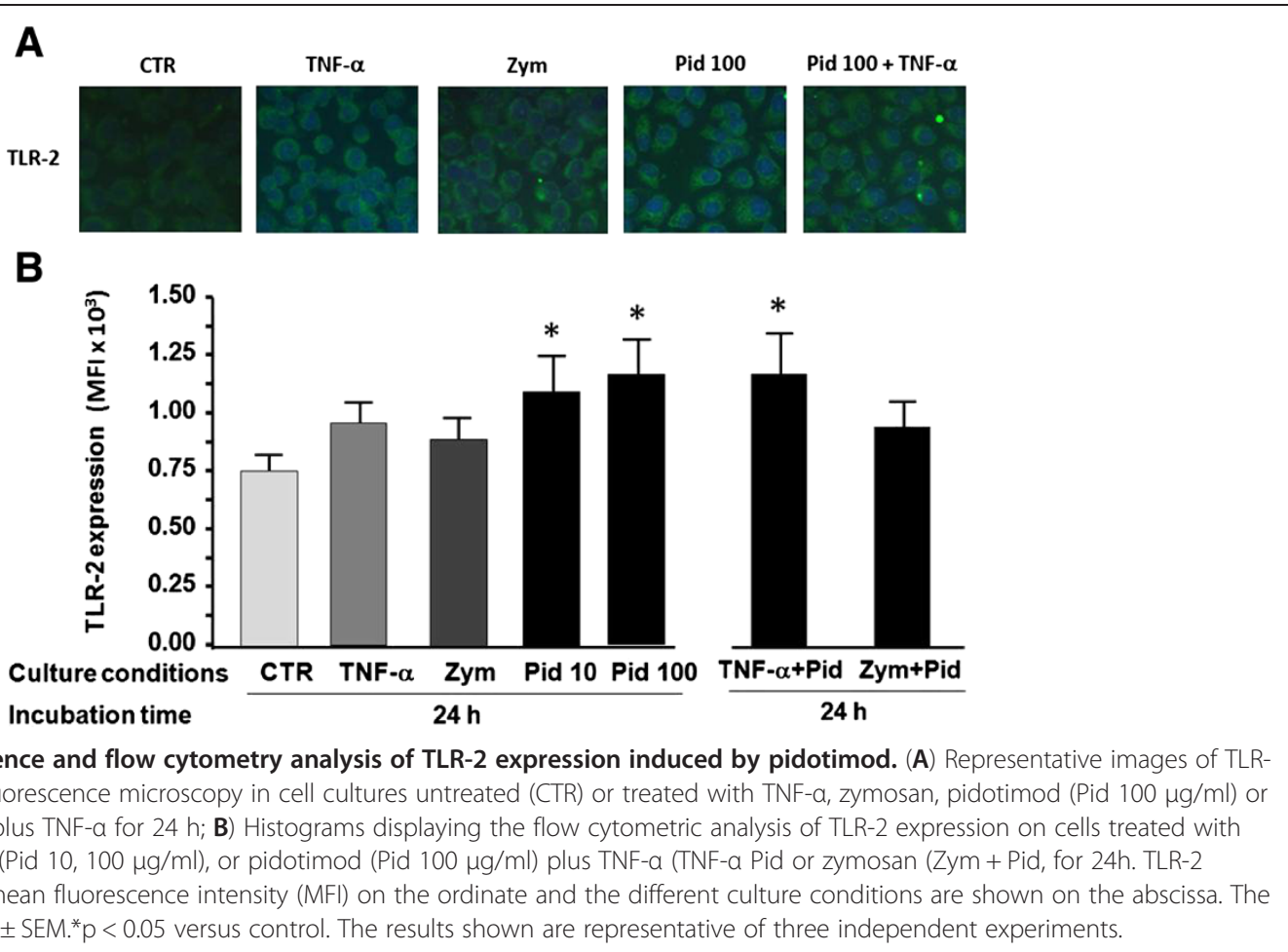

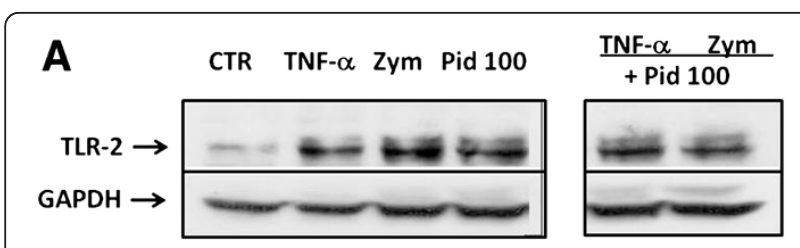

B

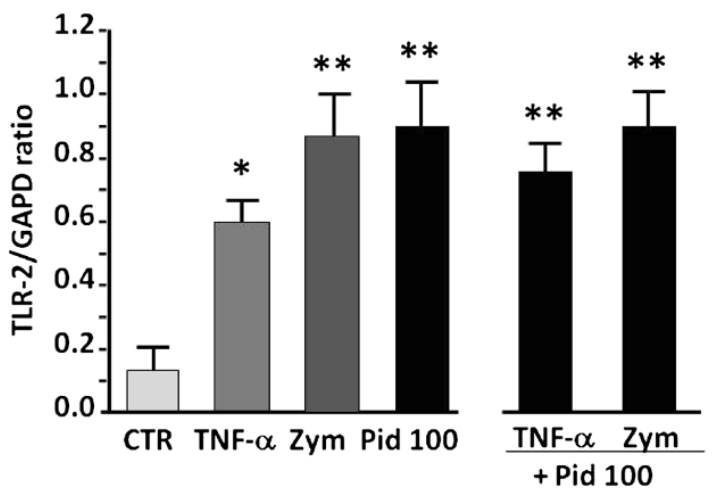

Figure 3 Western blot analysis of TLR-2 expression induced by pidotimod. (A) Representative western blot of TLR-2 and GAPDH expression of BEAS-2B incubated with medium alone (CTR) or treated with TNF-a, zymosan (Zym), pidotimod (Pid $100 \mu \mathrm{g} / \mathrm{ml}$ ) or pidotimod (Pid $100 \mu \mathrm{g} / \mathrm{ml}$ ) plus TNF-a or zymosan (Zym), for $24 \mathrm{~h}$. (B) The densitometric analysis of TLR-2 expression, normalized to GAPDH, is shown on the ordinate and the different culture conditions on the abscissa. The data are expressed as mean \pm SEM. ${ }^{*} p<0.05$ and ${ }^{* *} p<0.01$ versus control. The results shown are representative of three independent experiments. detected by western blot analysis of cytoplasmic and nuclear extracts. NF-kB p-65 expression was upregulated in the cytoplasmic compartment after exposure to TNF$\alpha$ or pidotimod and associated with NF-kB nuclear translocation (Figure 6A and B). Similar results were obtained in the experiments performed with pidotimod $10 \mu \mathrm{g} / \mathrm{ml}$ (not shown).

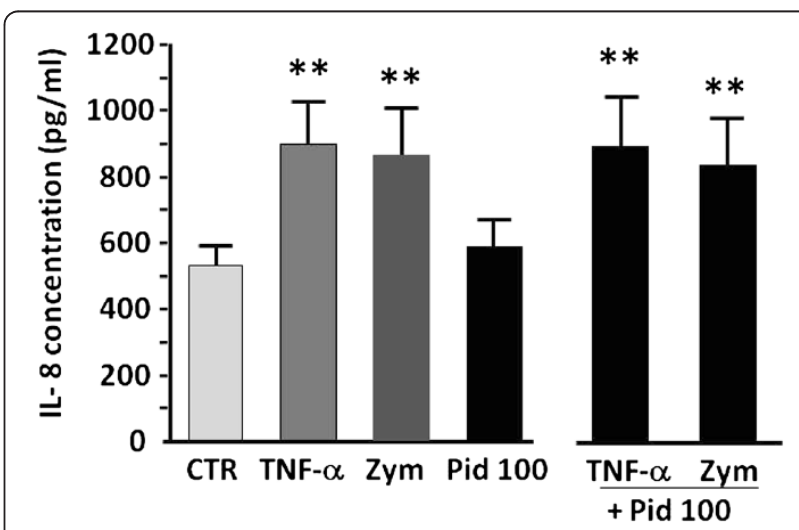

Figure 4 Assessment of IL-8 secretion. IL-8 concentration in the supernatants of BEAS-2B incubated with medium alone (CTR) or treated with TNF-a zymosan (Zym), pidotimod (Pid $100 \mu \mathrm{g} / \mathrm{ml}$ ), TNF- $a$ and pidotimod (TNF-a, Pid or zymosan and pidotimod (Zym + Pid for 24 h, evaluated by ELISA. IL-8 are expressed as mean \pm SEM. ${ }^{* *} p<0.01$ versus control. 


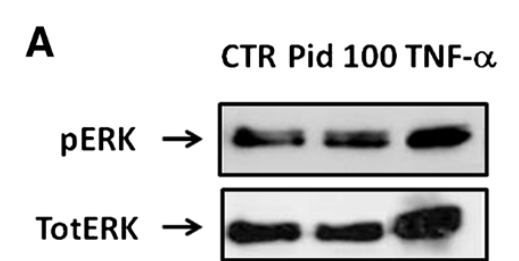

B

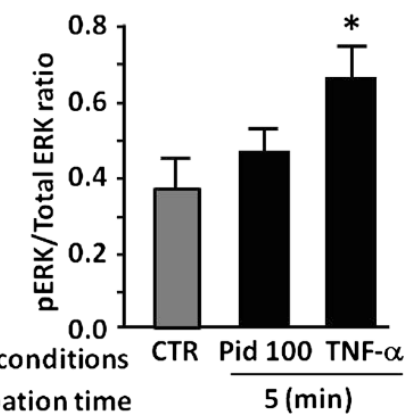

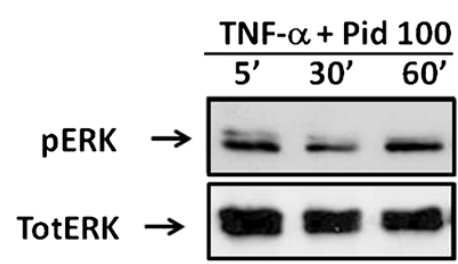

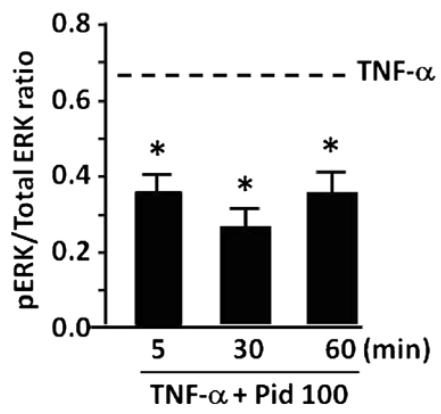

Figure 5 Detection by Western blot of ERK1/2 phosphorylation. (A) Representative western blot of phosphorylated and total ERK1/2 of BEAS-2B cells untreated (CTR) or exposed to TNF-a or pidotimod (Pid) for 5 min or TNF-a with pidotimod (TNF-a + Pid) for 5 to 60 min. (B) The densitometric analysis of ERK1/2 phosphorylation, normalized to total ERK1/2 is shown on the ordinate and the different culture conditions on the abscissa. The data are expressed as mean \pm SEM.* $p<0.05$ versus control. The results shown are representative of three independent experiments.

\section{Discussion}

Using the BEAS-2B human bronchial epithelial cells line we have shown that pidotimod is able to induce in vitro cellular changes potentially useful in enhancing the capability of the host to fight respiratory infections. We found that exposure of BEAS-2B cells to pidotimod had no effect on ICAM-1 expression and IL- 8 release, while a detectable upregulation of TLR-2 expression was observed by fluorescence microscopy, cytofluorimetry and western blot analysis. Pidotimod was also effective in inducing a remarkable inhibition of TNF- $\alpha$-induced ERK1/2 phosphorylation and, at the opposite, a significant increase in NF-kB protein expression and NF-kB nuclear translocation.

Pidotimod is a synthetic dipeptide molecule with biological and immunological activity on both the adaptive
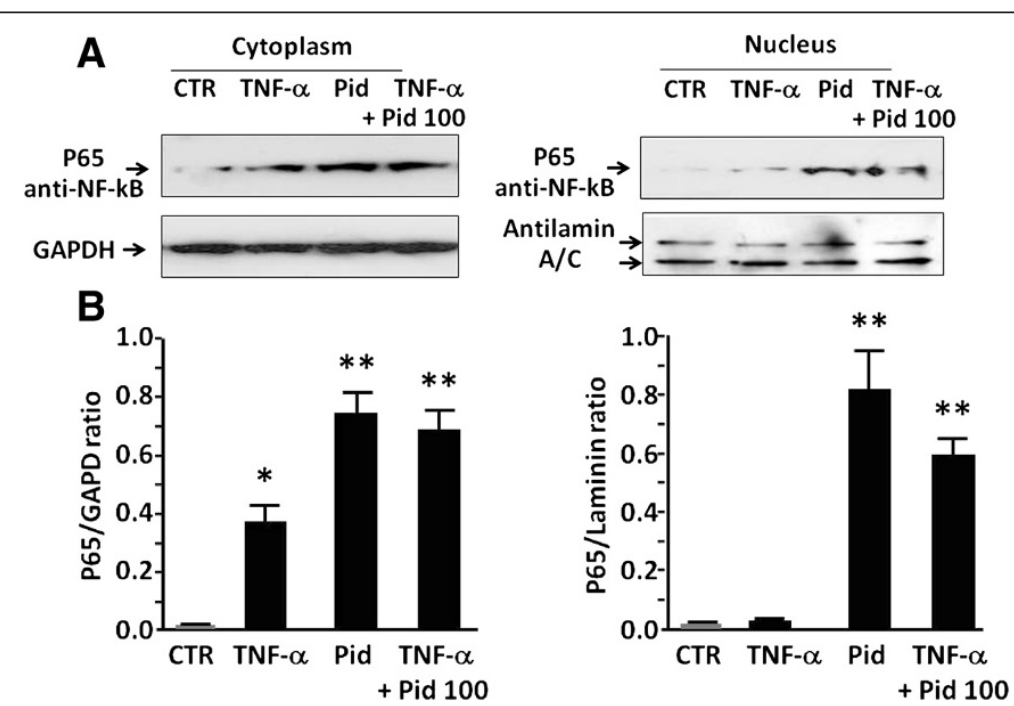

Figure 6 Detection by Western blot of NF-kB expression. (A) Representative western blots for NF-kB p65 levels in the cytoplasm and in the nuclear extracts of BEAS-2B cultured with medium alone (CTR) or exposed to TNF-a, $100 \mu \mathrm{g} / \mathrm{ml}$ pidotimod (Pid 100), or TNF-a and pidotimod (TNF-a + Pid 100) for $24 \mathrm{~h}$. GAPDH and Laminin A/C were used as housekeeping protein. (B) The densitometric analysis of NF-kB data, normalized to GAPDH (cytoplasm) or laminin A/C (nucleus), are shown on the ordinate and the different culture conditions on the abscissa. The data are expressed as mean \pm SEM. ${ }^{*} p<0.05$ versus control. The results shown are representative of three independent experiments. 
and the innate immune responses [25]. In vitro studies, both from animal and human specimens, have demonstrated a significant activity on both the innate and the adaptive immune responses, explaining the remarkable results of the clinical studies, where reduction in the rate of recurrent infections of the upper respiratory tract has been observed [25-27].

Emerging evidence from epidemiologic, clinical and animal studies indicates that viral infections, the leading cause of respiratory morbidity in young children, is an important environmental stimulus for airway injury and remodeling, resulting in bronchial hyperreactivity, impaired lung function and, potentially, persistent asthma [28]. The availability of PCR techniques has lead to a significant improvement in virus detection rate and shown that HRVs, principally known as the "common cold" viruses, are involved in the pathogenesis of wheezing disorders in $41-45 \%$ of young children [29]. Approximately $90 \%$ of the different HRV serotypes known utilize, as specific receptor ICAM-1, a molecule expressed on the surface of airway epithelial cells [30]. HRV infection upregulates ICAM-1 expression on airway epithelial cells, thus facilitating further viral attachment and entry [31]. Besides being a major receptor for HRVs, ICAM-1 is also involved in the transmigration across airway epithelial monolayers of neutrophils and their activation [32], and in disorders characterized by neutrophil-mediated acute lung injury [33]. Therefore the observation that in our experimental model pidotimod did not increase the constitutive or the TNF- $\alpha$-induced ICAM-1 expression may be interpreted as a "protective function", to avoid enhanced susceptibility to human HRV and neutrophil-mediated damage to the airway surface. A similar interpretation can be made for the results on IL- 8 release.

IL-8 is a powerful chemotactic and paracrine mediator for neutrophils, and infiltration of activated neutrophils play a key role in pulmonary inflammation and oxidative injury [34], a characteristic feature of respiratory viral infections $[35,36]$.

On the contrary, pidotimod enhanced the constitutive TLR-2 expression, raising questions on the activity of pidotimod on airway epithelial cells. The expression of surface molecules (such as ICAM-1 and TLR-2) is regulated not only by different stimuli $[31,37,38]$ but also by dissimilar intracellular pathways that may be triggered by the same stimulus [38-41]. An example is the activity of IFN- $\gamma$, able to have opposite effects on ICAM-1 and TLR-2 expression (up- and down-regulation, respectively) on different cell types $[37,38,42]$. The characteristics of pidotimod, to be able to regulate differently the expression of surface molecules has already been demonstrated by Gourgiotis D. and co-workers [43]. Using blood mononuclear cells, isolated from atopic asthmatic and normal children, they showed that through unknown intracellular mechanisms pidotimod downregulated the expression of CD30 induced by phytohaemoagglutinin but had no effect on human leukocyte antigen (HLA)-DR molecules [43].

TLRs are a class of proteins that play a key role in the innate immune system, recognizing structurally conserved molecules derived from microbes [44]. TLRs are a type of pattern recognition receptor and recognize molecules that are broadly shared by pathogens but distinguishable from host molecules, collectively referred to pathogen-associated molecular patterns (PAMPs). Of the ten mammalian TLR proteins identified thus far, TLR-2 seems to be the least discriminating, since it recognizes many bacterial, fungal, viral, and certain endogenous substances $[44,45]$. Recognition of PAMPs results in internalization and phagocytosis of bound molecules and in cellular activation with release of cytokines, chemokines and various interleukins $[44,45]$. Cytokines participating in this "nonspecific" immune defense include various interleukins, such as TNF- $\alpha, \mathrm{IL}-1 \alpha$, IL-1 $\beta$, IL-6, IL- 8 and IL-12. PAMPs-TLR interactions on the surface of the cells are sufficient to activate the $\mathrm{Ca} 2^{+}$ fluxes associated with induction of NF-kB in the airway [46]. Recent studies have implicated TLR, and especially TLR-2 and TLR-4, as sentinel receptors able to signaling the interaction of the host cells with bacterial pathogens via an NF-kB-mediated pathway [47]. Interestingly, using murine macrophages it was shown that TLR-2 mRNA may be induced after bacterial infection with the involvement of several cytokines, including IL-1 $\alpha$, and GM-CSF, but that NF-kB is necessary for maximal TLR-2 transcription [48], further underlining the tight connections between $\mathrm{NF}-\mathrm{kB}$ and TLR-2.

The different effects of pidotimod on BEAS-2B cells here reported may be at least partially explained by the opposite effects on some cell functions produced by ERK1/2 phosphorylation or NF-kB activation.

Extracellular-signal-regulated kinases (ERKs) or classical mitogen-activated protein (MAP) kinases are widely expressed protein kinase intracellular signalling molecules that are engaged in the regulation of meiosis, mitosis, but also in several post mitotic functions, including activities involved in inflammatory and defense processes $[49,50]$. These include opposite effects on ICAM-1 and TLR-2 expression. In agreement with our results on BEAS-2B cells, stimulation of ERK1/2 phosphorylation by cysteinyl leukotriene D4 resulted in an increased ICAM-1 expression by $16 \mathrm{HBE}$ bronchial epithelial cells, associated with enhanced eosinophil adhesion [51]. In contrast, inhibition of ERK1/2 phosphorylation [52] by up-regulation of MAP kinase phosphatase- 1 by glucocorticoids increased TLR-2 expression by HeLa epithelial cells.

NF-kB is a protein complex, found in almost all animal cell types, that controls DNA transcription and is involved in cellular responses to a variety of stimuli such including bacterial or viral antigens $[53,54]$. NF-kB plays 
a key role in regulating a quick immune response to infections because it belongs to the category of "rapid-acting" primary transcription factors, i.e. present in cells in an inactive state and not requiring new protein synthesis to be activated and is involved in the regulation of reactive oxygen species, cytokines and adhesion molecules production [54-57].

The identification of TLRs as specific pattern recognition molecules and the finding that, not only their expression is regulated by NF-kB [42], but also that TLR stimulation leads to NF-kB activation has improved our understanding on both the innate and the adaptive immune responses to infections.

Surprisingly, NF-kB activation induced by pidotimod did not result in an increase in IL-8 release. However, in human airway epithelial cell cultures and in mice inhibition of ERK1/2 phosphorylation suppress IL-8 production induced by exposure to sub toxic doses of cadmium [58]. Moreover, other transcriptional factors are involved in IL-8 production and release, including activator protein 1 (AP-1), and signal transducer and activator of transcription proteins (STAT) [59,60]. Rather than pidotimod, elevated intracellular levels of reactive oxygen species (ROS) in lung epithelial cells can activate these pathways $[60,61]$. Therefore, upstream of these transcriptional factors, ROS-sensitive signaling pathways, including mitogen-activated protein kinases and protein kinase $\mathrm{C}$, may be involved in the increase in inflammatory gene activation $[56,57]$.

\section{Conclusion}

We have shown that pidotimod, a synthetic dipeptide used in the prevention of recurrent respiratory infection in children, is able to modulate airway epithelial cells functions involved in host-virus possibly through NF-kB activation. The obvious limitation of the study is that the experiments here reported were obtained in a human cell line. If confirmed in vivo, these activities may, at least in part, clarify the mechanism of action of this molecule at airway level.

\footnotetext{
Abbreviations

HRV: Human rhinovirus; RIS: Respiratory insufficiency syndrome; TNF-a: Tumor necrosis factor-a; RANTES: Regulated by activation normal T cell expressed and secreted; ICAM-1: Intercellular adhesion molecule-1; TLR-2: Toll-like receptor-2; IL: Interleukin; NF-kB: Nuclear factor-kappa B; ERK: Extracellularsignal-regulated kinase; ELISA: Enzyme-linked immunosorbent assay; DTT: Dithiothreitol; IFN-y: Interferon- y; HLA-DR: Human leukocyte antigen-DR; PAMP: Pathogen-associated molecular pattern; MAP kinase: Mitogen-activated protein kinase; AP: Activator protein; STAT: Signal transducer and activator of transcription proteins; ROS: Reactive oxygen species.
}

\section{Competing interests}

GAR. Received in the past five years reimbursements, fees and funding from Polichem S.A., Luxembourg and Valeas S.p.A., Milan, Italy, that way gain or lose financially from the publication of this manuscript.

SC and MS do not declare any-financial competing interests.

\section{Authors' contributions}

All the authors have made substantial contributions to conception and design of the study, to the analysis, interpretation and acquisition of data of the data. SC performed all the in vitro experiments and MS the statistical analysis. 2) All the authors have been involved in drafting the manuscript and revising it critically for important intellectual content. All authors read and approved the final manuscript.

\section{Acknowledgements}

The authors thank Annalisa Firenze provided technical help and writing assistance.

\section{Sources of funding}

This research was funded by Ricerca Corrente, Italian Ministry of Health, Rome, Italy. Valeas S.p.A., Milan financed the study related to this manuscript, including the article-processing charge.

Received: 22 January 2013 Accepted: 30 April 2013

Published: 10 May 2013

\section{References}

1. Wald ER, Guerra N, Byers C: Upper respiratory tract infections in young children: duration of and frequency of complications. Pediatrics 1991, 87:129-133.

2. Harsten G, Prellner K, Heldrup J, Kalm O, Kornfalt R: Acute respiratory-tract infections in children. A 3-year follow-up from birth. Acta Paediatr Scand 1990, 79:402-409.

3. Benediktsdottir B: Upper airway infections in preschool childrenfrequency and risk factors. Scand J Prim Health Care 1993, 11:197-201.

4. Banz K, Schwicker D, Thomas AM: Economic evaluation of immunoprophylaxis in children with recurrent ear, nose and throat infections. PharmacoEconomics 1994, 6:464-477.

5. Cohen R, Just J, Koskas M, Bingen E, Boucherat M, Bourrillon A, Foucaud P, François M, Garnier JM, Guillot M, Ployet MJ, Schlemmer C, Gaudelus J: Recurrent respiratory tract infections: how should we investigate and treat? Arch Pediatr 2005, 12:183-190.

6. Heikkinen T, Järvinen A: The common cold. Lancet 2003, 361:51-59.

7. Principi N, Bosis S, Esposito S: Human metapneumovirus in paediatric patients. Clin Microbiol Infect 2006, 12:301-308.

8. Kieninger $E$, Fuchs $O$, Latzin P, Frey $U$, Regamey N: Rhinovirus infections in infancy and early childhood. Eur Respir J 2012. Epub ahead of print.

9. Rennard SI, Romberger DJ, Sisson JH, Von Essen SG, Rubinstein I, Robbins RA, Spurzem JR: Airway epithelial cells: functional roles in airway disease. Am J Respir Crit Care Med 1994, 150(5 Pt 2):S27-S30.

10. Sacco O, Silvestri M, Sabatini F, Sale R, Defilippi AC, Rossi GA: Epithelial cells and fibroblasts: structural repair and remodelling in the airways. Paediatr Respir Rev 2004, 5(Suppl A):S35-S40.

11. Lambrecht $B N$, Hammad H: The airway epithelium in asthma. Nat Med 2012, 18:684-692.

12. Saito T, Deskin RW, Casola A, Häeberle H, Olszewska B, Ernst PB, Alarm R, Ogra PL, Garofalo L: Respiratory syncytial virus induces selective production of the chemokine RANTES by upper airway epithelial cells. $J$ Infect Dis 1997, 175:497-504.

13. McNamara PS, Flanagan BF, Hart CA, Smyth RL: Production of chemokines in the lungs of infants with severe respiratory syncytial virus bronchiolitis. J Infect Dis 2005, 191:1225-1232.

14. Greiff $L$, Venge $P$, Andersson M, Enander I, Linden M, Myint S, Persson CG: Effects of rhinovirus-induced common colds on granulocyte activity in allergic rhinitis. J Infect 2002, 45:227-232.

15. Message SD, Johnston SL: The immunology of virus infection in asthma. Eur Respir J 2001, 18:1013-1025.

16. Ball TM, Holberg CJ, Aldous MB, Martinez FD, Wright AL: Influence of attendance at day care on the common cold from birth through 13 years of age. Arch Pediatr Adolesc Med 2002, 156:121-126.

17. Ciprandi G, Tosca MA, Fasce L: Allergic children have more numerous and severe respiratory infections than non-allergic children. Pediatr Allergy Immunol 2006, 17:389-391.

18. Bossuyt X, Moens L, Van Hoeyveld E, Jeurissen A, Bogaert G, Sauer K, Proesmans M, Raes M, De Boeck K: Coexistence of (partial) immune defects and risk of recurrent respiratory infections. Clin Chem 2007, 53:124-130 
19. Rossi GA, Peri C, Raynal ME, Defilippi AC, Risso FM, Schenone G, Pallestrini E, Melioli G: Naturally occurring immune response against bacteria commonly involved in upper respiratory tract infections: analysis of the antigen-specific salivary lgA levels. Immunol Lett 2003, 86:85-91.

20. Giagulli C, Noerder M, Avolio M, Becker PD, Fiorentini S, Guzman CA, Caruso A: Pidotimod promotes functional maturation of dendritic cells and displays adjuvant properties at the nasal mucosa level. Int Immunopharmacol 2009, 9:1366-1373.

21. Reddel RR, Ke Y, Gerwin BI, McMenamin MG, Lechner JF, Su RT, Brash DE, Park JB, Rhim JS, Harris CC: Transformation of human bronchial epithelial cells by infection with SV40 or adenovirus-V40 hybrid virus, or transfection via strontium phosphate coprecipitation with a plasmid containing SV40 early region genes. Cancer Res 1988, 48:1904-1909.

22. Silvestri M, Serpero L, Petecchia L, Sabatini F, Cerasoli F Jr, Rossi GA: Cytokineactivated bronchial epithelial cell pro-inflammatory functions are effectively downregulated in vitro by ciclesonide. Pulm Pharmacol Ther 2006, 19:210-217.

23. Petecchia L, Sabatini F, Usai C, Caci E, Varesio L, Rossi GA: Cytokines induce tight junction disassembly in airway cells via an EGFR-dependent MAPK/ ERK1/2-pathway. Lab Invest 2012, 92:1140-1148.

24. Donnelly RP, Crofford LJ, Freeman SL, Buras J, Remmers E, Wilder RL, Fenton MJ: Tissue-specific regulation of IL-6 production by IL-4. Differential effects of IL-4 on nuclear factor-kappa B activity in monocytes and fibroblasts. J Immunol 1993, 151:5603-5612.

25. Riboldi P, Gerosa M, Meroni PL: Pidotimod: a reappraisal. Int J Immunopathol Pharmacol 2009, 22:255-262.

26. Del-Rio-Navarro BE, Espinosa Rosales F, Flenady V, Sienra-Monge JJ: Immunostimulants for preventing respiratory tract infection in children. Cochrane Database Syst Rev 2006, 4:CD004974

27. De la Torre GC, Pacheco Ríos A, Escalante Domínguez AJ, del Río Navarro BE: Comparative meta-analysis of immunoestimulant agents used in pediatric patients in Mexico. Rev Alerg Mex 2005, 52:25-38.

28. Gern JE, Rosenthal LA, Sorkness RL, Lemanske RF Jr: Effects of viral respiratory infections on lung development and childhood asthma. J Allergy Clin Immunol 2005, 115:668-674.

29. Heymann PW, Carper HT, Murphy DD, Platts-Mills TA, Patrie J, Mclaughlin AP, Erwin EA, Shaker MS, Hellems M, Peerzada J, Hayden FG, Hatley TK, Chamberlain R: Viral infections in relation to age, atopy, and season of admission among children hospitalized for wheezing. J Allergy Clin Immunol 2004, 114:239-247.

30. Oddera S, Silvestri M, Lantero S, Sacco O, Rossi GA: Downregulation of the expression of intercellular adhesion molecule (ICAM)-1 on bronchial epithelial cells by a beta2-adrenoceptor agonist: fenoterol. J Asthma 1998, 35:401-408.

31. Papi A, Papadopoulos NG, Stanciu LA, Bellettato CM, Pinamonti S, Degitz K, Holgate ST, Johnston SL: Reducing agents inhibit rhinovirus-induced up-regulation of the rhinovirus receptor intercellular adhesion molecule1 (ICAM-1) in respiratory epithelial cells. FASEB J 2002, 16:1934-1936.

32. Kidney JC, Proud D: Neutrophil transmigration across human airway epithelial monolayers: mechanisms and dependence on electrical resistance. Am J Respir Cell Mol Biol 2000, 23:389-395.

33. Mulligan MS, Smith CW, Anderson DC, Todd RF 3rd, Miyasaka M, Tamatan $T$, Issekutz TB, Ward PA: Role of leukocyte adhesion molecules in complement-induced lung injury. J Immunol 1993, 150:2401-2406.

34. Strieter RM, Kunkel SL: Acute lung injury: the role of cytokines in the elicitation of neutrophils. J Investig Med 1994, 42:640-651.

35. Everard ML, Swarbrick A, Wrightham M, McIntyre J, Dunkley C, James PD, Sewell $H F$, Milner AD: Analysis of cells obtained by bronchial lavage of infants with respiratory syncytial virus infection. Arch Dis Child 1994, 71:428-432.

36. Huang SH, Cao XJ, Liu W, Shi XY, Wei W: Inhibitory effect of melatonin on lung oxidative stress induced by respiratory syncytial virus infection in mice. J Pineal Res 2010, 48:109-116.

37. Othumpangat S, Regier M, Piedimonte G: Nerve growth factor modulates human rhinovirus infection in airway epithelial cells by controlling ICAM1 expression. Am J Physiol Lung Cell Mol Physiol 2012, 302:1057-1066.

38. Flo TH, Halaas O, Torp S, Ryan L, Lien E, Dybdahl B, Sundan A, Espevik T: Differential expression of Toll-like receptor 2 in human cells. J Leukoc Biol 2001, 69:474-481.

39. Oh JH, Park EJ, Park JW, Lee J, Lee SH, Kwon TK: A novel cyclin-dependent kinase inhibitor down-regulates tumor necrosis factor-alpha (TNF-alpha)induced expression of cell adhesion molecules by inhibition of NF-kappaB activation in human pulmonary epithelial cells. Int Immunopharmacol 2010, 10:572-579.
40. Lin FS, Lin CC, Chien CS, Luo SF, Yang CM: Involvement of p42/p44 MAPK, JNK, and NF-kappaB in IL-1beta-induced ICAM-1 expression in human pulmonary epithelial cells. Cell Physiol 2005, 202:464-473.

41. Talreja J, Kabir MH, B Filla M, Stechschulte DJ, Dileepan KN: Histamine induces Toll-like receptor 2 and 4 expression in endothelial cells and enhances sensitivity to Gram-positive and Gram-negative bacterial cell wall components. Immunology 2004, 113:224-233.

42. Papon JF, Coste A, Gendron MC, Cordonnier C, Wingerstmann L, Peynègre R, Escudier E: HLA-DR and ICAM-1 expression and modulation in epithelial cells from nasal polyps. Laryngoscope 2002, 112:2067-2075.

43. Gourgiotis D, Papadopoulos NG, Bossios A, Zamanis P, Saxoni-Papageorgiou $\mathrm{P}$ : Immune modulator pidotimod decreases the in vitro expression of CD30 in peripheral blood mononuclear cells of atopic asthmatic and normal children. J Asthma 2004, 41:285-287.

44. Akira S, Takeda K, Kaisho T: Toll-like receptors: critical proteins linking innate and acquired immunity. Nat Immunol 2001, 2:675-680.

45. Akira S, Takeda K: Toll-like receptor signalling. Nat Rev Immunol 2004 , 4:499-511.

46. Ratner AJ, Bryan R, Weber A, Nguyen S, Barnes D, Pitt A, Gelber SE, Cheung A, Prince $\mathrm{A}$ : Cystic fibrosis pathogens activate $\mathrm{Ca}_{2}^{+}$dependent MAPK signaling pathways in airway epithelial cells. J Bio/ Chem 2001, 276:19267-19275.

47. Wang T, Lafuse WP, Zwilling BS: Regulation of toll-like receptor 2 expression by macrophages following Mycobacterium avium infection. J Immunol 2000, 165:6308-6313.

48. Wang T, Lafuse WP, Zwilling BS: NFkappaB and Sp1 elements are necessary for maximal transcription of toll-like receptor 2 induced by Mycobacterium avium. J Immunol 2001, 167:6924-6932.

49. Chang L, Karin M: Mammalian MAP kinase signalling cascades. Nature 2001, 410:37-40.

50. Agell N, Bachs O, Rocamora N, Villalonga P: Modulation of the Ras/Raf/ MEK/ERK pathway by $\mathrm{Ca2}^{+}$, and calmodulin. Cell Signal 2002, 14:649-654

51. Profita M, Sala A, Bonanno A, Siena L, Ferraro M, Di Giorgi R, Montalbano AM, D. Albano G, Gagliardo R, Gjomarkaj M: Cysteinyl leukotriene-1 receptor activation in a human bronchial epithelial cell line leads to signal transducer and activator of transcription 1-mediated eosinophil adhesion. The American Society for Pharmacology and Experimental Therapeutics 2008, 325:1024-1030.

52. Imasato A, Desbois-Mouthon C, Han J, Kai H, Cato AC, Akira S, Li JD: Inhibition of p38 MAPK by glucocorticoids via induction of MAPK phosphatase-1 enhances nontypeable Haemophilus influenzae-induced expression of toll-like receptor 2. J Biol Chem 2002, 277:47444-47450

53. Gilmore TD: Introduction to NF-kB: players, pathways, perspectives. Oncogene 2006, 25:6680-6684.

54. Brasier AR: The NF-kB regulatory network. Cardiovasc Toxicol 2006, 6:111-130.

55. Perkins ND: Integrating cell-signalling pathways with NF-kB and IKK function. Nat Rev Mol Cell Biol 2007, 8:49-62.

56. Qin H, Wilson CA, Lee SJ, Zhao X, Benveniste EN: LPS induces CD40 gene expression through the activation of NF-kappaB and STAT-1alpha in macrophages and microglia. Blood 2005, 106:3114-3122.

57. Barnes PJ: Pathophysiology of allergic inflammation. Immunol Rev 2011, 242:31-50.

58. Cormet-Boyaka E, Jolivette K, Bonnegarde-Bernard A, Rennolds J, Hassan F, Mehta P, Tridandapani S, Webster-Marketon J, Boyaka PN: An NF-kB-independent and Erk1/2-dependent mechanism controls CXCL8/L-8 responses of airway epithelial cells to cadmium. Toxicol Sci 2012, 125:418-429.

59. Mio T, Romberger DJ, Thompson AB, Robbins RA, Heires A, Rennard SI: Cigarette smoke induces interleukin- 8 release from human bronchial epithelial cells. Am J Respir Cri Care Med 1997, 155:1770-1776.

60. Witherden IR, Vanden Bon EJ, Goldstraw P, Ratcliffe C, Pastorino U, Tetley TD: Primary human alveolar type II epithelial cell chemokine release: effects of cigarette smoke and neutrophil elastase. Am J Respir Cell Mol Biol 2004, 30:500-509.

61. Rahman I, MacNee W: Regulation of redox glutathione levels and gene transcription in lung inflammation: therapeutic approaches. Free Radic Biol Med 2000, 28:1405-1420.

doi:10.1186/1824-7288-39-29

Cite this article as: Carta et al:: Modulation of airway epithelial cell functions by Pidotimod: NF-kB cytoplasmatic expression and its nuclear translocation are associated with an increased TLR-2 expression. Italian Journal of Pediatrics 2013 39:29. 